\title{
Cytological diagnosis of virus-infected cells in Papanicolaou smears and its application in clinical practice
}

\author{
D. V. COLEMAN
}

From the Department of Pathology, St Mary's Hospital Medical School, London W2 1NY, UK

SUMMARY The cytopathic changes of herpes simplex virus, varicella-zoster virus, the human polyomaviruses, and the trachoma agent can be recognised in smears prepared from a wide variety of specimens. The morphology of virus-infected cells is described, and the clinical value of these observations is discussed. Cytological diagnosis offers a rapid and convenient method of detecting infection with these viruses which can be confirmed by conventional virological method while the patient is still in the acute stages of the disease. Confirmation can also be made retrospectively by reprocessing cells, identified in the Papanicolaou smear, for electron microscopy. Screening for virus-infected cells in cytological smears is a technique that can be developed in any pathology laboratory prepared to provide a comprehensive cytology service, and it is proving to be a useful tool in clinical diagnosis and applied research.

In recent years, cytopathologists have observed that the alterations in cell morphology that accompany certain virus infections can be recognised in Papanicolaou smears submitted to routine examination by light microscopy. The cytopathic changes due to herpes simplex virus, varicella-zoster virus, cytomegalovirus, and the human polyomaviruses have been described in epithelial cells in cytological specimens such as cervical smears, urine, sputum, and conjunctival scrapes, and the presence of virusinfected cells in the smears has been shown to be a convenient and reliable guide to active infection of the patient with these viruses. These observations have widened the scope of the cytodiagnostic technique for they imply that the large numbers of cytological specimens that are submitted routinely for examination for malignant cells can at the same time be screened for evidence of viral activity.

The aim of this paper is to describe the morphology of virus-infected cells in Papanicolaou-stained smears and to discuss the value of these observations in clinical practice. The identification of cytological markers of virus disease can alert the clinician to viral illness in his patient when none is suspected and can provide him with a differential diagnosis when

Received for publication 7 March 1979 the services of a virology laboratory are not immediately to hand. Moreover, cytology can provide a rapid method of screening for viruses that are not readily isolated.

Throughout this paper emphasis is placed on the fact that cytological manifestations of viral activity provide presumptive evidence only of active infection with a specific virus or group of viruses. Whenever possible the cytodiagnosis should be confirmed by conventional virological methods while the patient is still in the acute stages of the disease. As this is not always possible, an alternative method of confirming the cytodiagnosis is discussed in this paper. This involves the reprocessing of selected cells in the Papanicolaou smear for electron microscopy and is described more fully in the section on the human polyomaviruses.

\section{Cytodiagnosis of genital herpes in the female patient}

The cytological diagnosis of genital herpes depends upon the recognition of multinucleate giant squamous cells in Papanicolaou-stained smears (Figs 1 to 3 ). These cells were first described in cervical smears by Stern and Longo (1963), who realised their potential value as markers of viral infection. Infection with herpes simplex virus is characterised by cell fusion with the formation of 


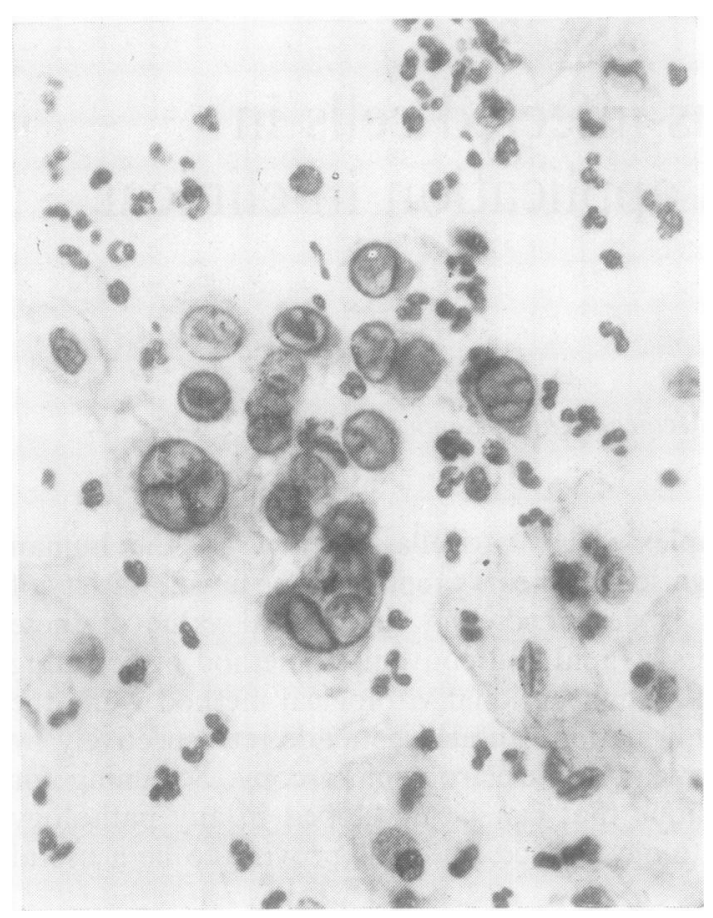

Fig. 1 Multinucleate and single cells due to infection with herpes simplex virus. The nuclei of two of the single cells contain inclusions. Cervical smear. Papanicolaou $\times 400$

large syncytia of epithelial cells $500-200 \mu$ in diameter. These are easy to locate during routine screening with low-power microscope objectives and may contain up to 30 nuclei in tight aggregates. Each nucleus has a clearly defined outline as a result of the heavy deposition of chromatin beneath the nuclear membrane, and the nuclear shape appears moulded by adjacent nuclei. Nuclei may contain a large, centrally placed acidophilic inclusion surrounded by a clear halo (Fig. 3); but not infrequently the nuclei are devoid of inclusion bodies and present an empty, ballooned, 'ground-glass' appearance, the substance of which takes up an amphophilic stain (Figs 1 and 2). It is important to remember that the absence of inclusion bodies does not invalidate the diagnosis. The presence of inclusion bodies merely represents an advanced stage of the disease and is not, as some authors suggest, evidence of recurrent infection. The smears may contain many polymorphs if ulceration is present, and Trichomonas vaginalis and monilia may also be identified. Many single squamous and columnar cells may show evidence of virus infection with ballooning of the nucleus, but these are not a

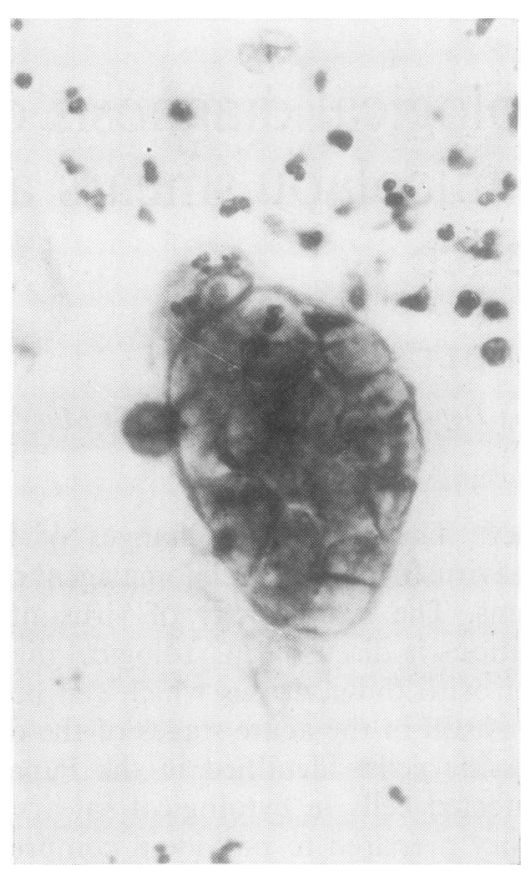

Fig. 2 Multinucleate giant epithelial cell characteristic of herpes simplex infection. Note moulding and groundglass appearance of nuclei which do not contain inclusions. Cervical smear. Papanicolaou $\times 1000$

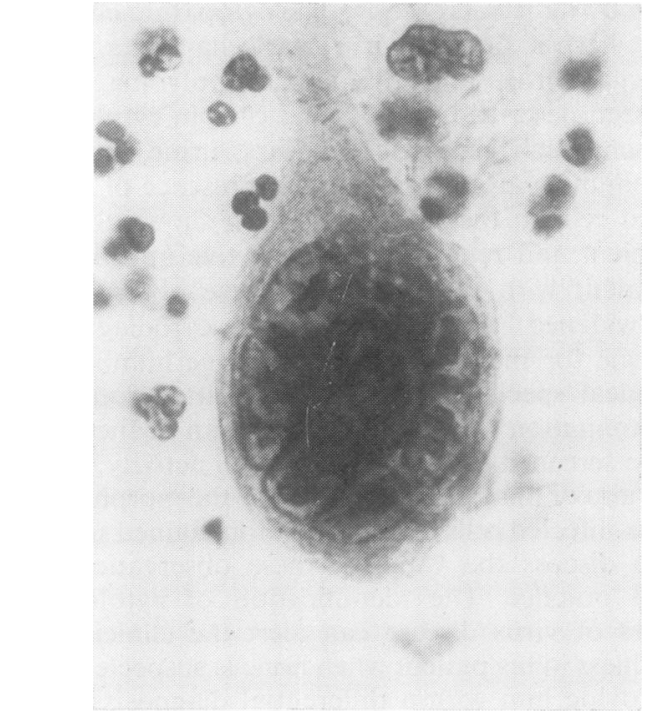

Fig. 3 Multinucleate giant cell containing intranuclear inclusions due to infection with herpes simplex virus. Cervical smear. Papanicolaou $\times 1000$ 
reliable index of viral infection and provide supportive evidence only.

The accuracy of the cytological method has been subject to careful review after reports of serious diagnostic errors whereby herpes-infected cells in cervical smears have been interpreted as malignant, resulting in unnecessary surgical intervention (Naib et al., 1966; An, 1969). In an attempt to ascertain the accuracy of a cytodiagnosis of herpes genitalis, Morse and her colleagues (1974) investigated 186 women attending a venereal diseases clinic for evidence of herpes simplex infection of the genital tract. Cervical smears and swabs for virus isolation were obtained at each clinic attendance, and the results were correlated with the clinical findings. Multinucleate giant cells were noted in cervical smears from eight patients, and herpes genitalis was confirmed by virus isolation and/or clinical evidence of infection in seven of the eight cases. Herpes simplex virus type 2 was isolated from the cervices of a further eight patients, none of whom had clinical evidence of genital viral infection or cytological atypia. These observations indicate that cervical screening is an effective way of detecting herpes simplex infection in half the women who are shedding virus. Cytology is a particularly useful method of detecting clinically inapparent infection. We have observed in these cases that multinucleate giant cells form in the cervical epithelium without vesicle formation (Fig. 4).

Although genital herpes is a self-limiting disease and clinical evidence of infection may be inapparent to patient and physician alike, a cytodiagnosis of herpes simplex virus infection of the uterine cervix carries with it a clinical significance which is defined in the following paragraphs.

1 The prevalence of genital herpes among women has been estimated from combined cytological and virological studies of women attending a venereal diseases clinic and gynaecological clinics (Morse et al., 1974). Evidence of genital herpes infection was found in $8.6 \%$ of women attending the venereal diseases clinic and in less than $1 \%$ of women attending the gynaecological outpatient clinic.

2 A high incidence of gonorrhoea has been observed among women with genital herpes, and in every case of herpes simplex infection an attempt should be made to demonstrate the gonococcus (Beilby et al., 1968; Morse et al., 1974). While bacteriological investigation for gonorrhoea is routine for patients attending venereal diseases clinics, it is not a test that is usually included in the examination of women attending gynaecological clinics, well women clinics, or family planning clinics. The cytologist should indicate to the clinician the need for this additional investigation whenever a cytological

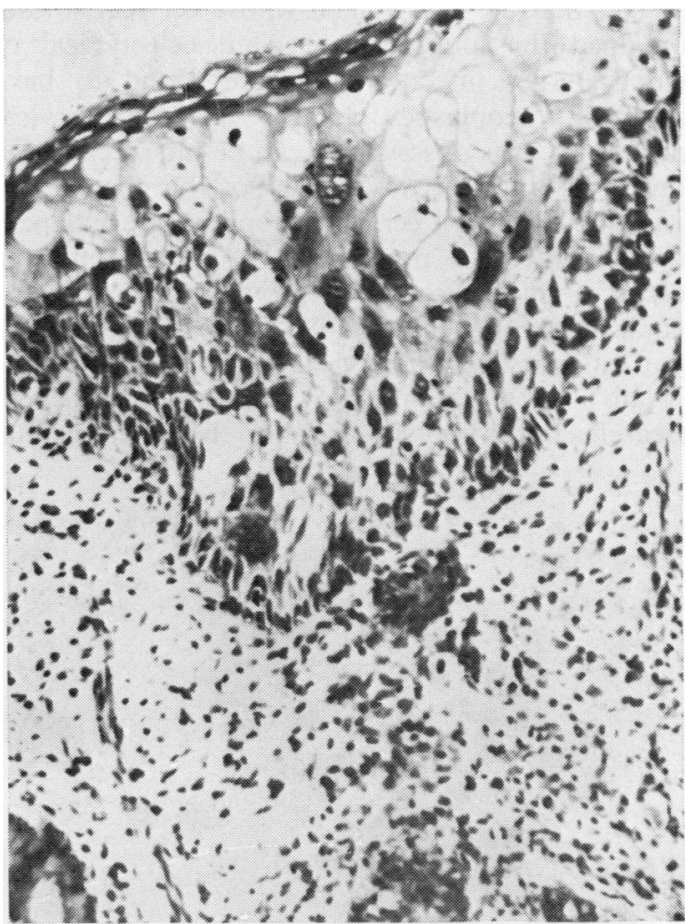

Fig. 4 Histological section of cervix from a woman aged 32 whose cervical smear contained multinucleate giant cells and malignant cells. The cervix appeared normal macroscopically. An area of carcinoma in situ was found in the biopsy specimen together with an area of epithelium containing numerous multinucleate giant cells. Herpes virus was isolated from the cervix. Haematoxylin and eosin $\times 100$

diagnosis of genital herpes is made in patients in whom venereal disease is not suspected.

3 Herpetic lesions of the uterine cervix can be confused clinically with cancer, and a cytological smear can assist in the differential diagnosis. The necrotising cervicitis of herpes may mimic a necrotic carcinoma (Willcox, 1968), and in pregnancy cervical herpes may even masquerade as a large, fungating tumour of the cervix. Stein and Siciliano (1966) described how surgical biopsy was inadequate in such a case as only necrotic tissue was seen in histological section. The multinucleate giant cells of herpes simplex were evident in the cervical smear, and the diagnosis was confirmed by virus isolation. The lesion resolved after a period of six weeks. Of course, carcinoma and genital herpes may occur together, with clear cytological evidence of both lesions in the Papanicolaou smear (see legend to Fig. 4).

$4 \mathrm{Naib}$ and his colleagues (1969) drew attention to 
the fact that, of 245 women whose cervical smears contained the multinucleate giant cell typical of genital herpes infection, 58 were found to have coexisting neoplastic changes in the cervical epithelium. This observation can be interpreted in a number of different ways. It is possible that herpes simplex type 2 and cervical neoplasia are independently related to promiscuity. Alternatively, the herpes simplex virus may grow preferentially in neoplastic epithelium. Finally, herpes simplex virus type 2 may itself be a cervical carcinogen.

Naib's observation provided a stimulus to research into the relationship between genital infection with herpes simplex virus type 2 and cervical cancer. Most investigations have taken the form of comparisons of the prevalence of neutralising antibody against herpes simplex virus type 2 in women with cervical cancer and in women without malignant disease matched for age, marital status, religion, and social class (Rawls et al., 1969; Nahmias et al., 1970; Royston and Aurelian, 1970). It was shown with some consistency that the prevalence of herpes simplex virus type 2 antibody was higher among women with cervical cancer than among controls. However, because herpes simplex virus type 1 and herpes simplex virus type 2 share common

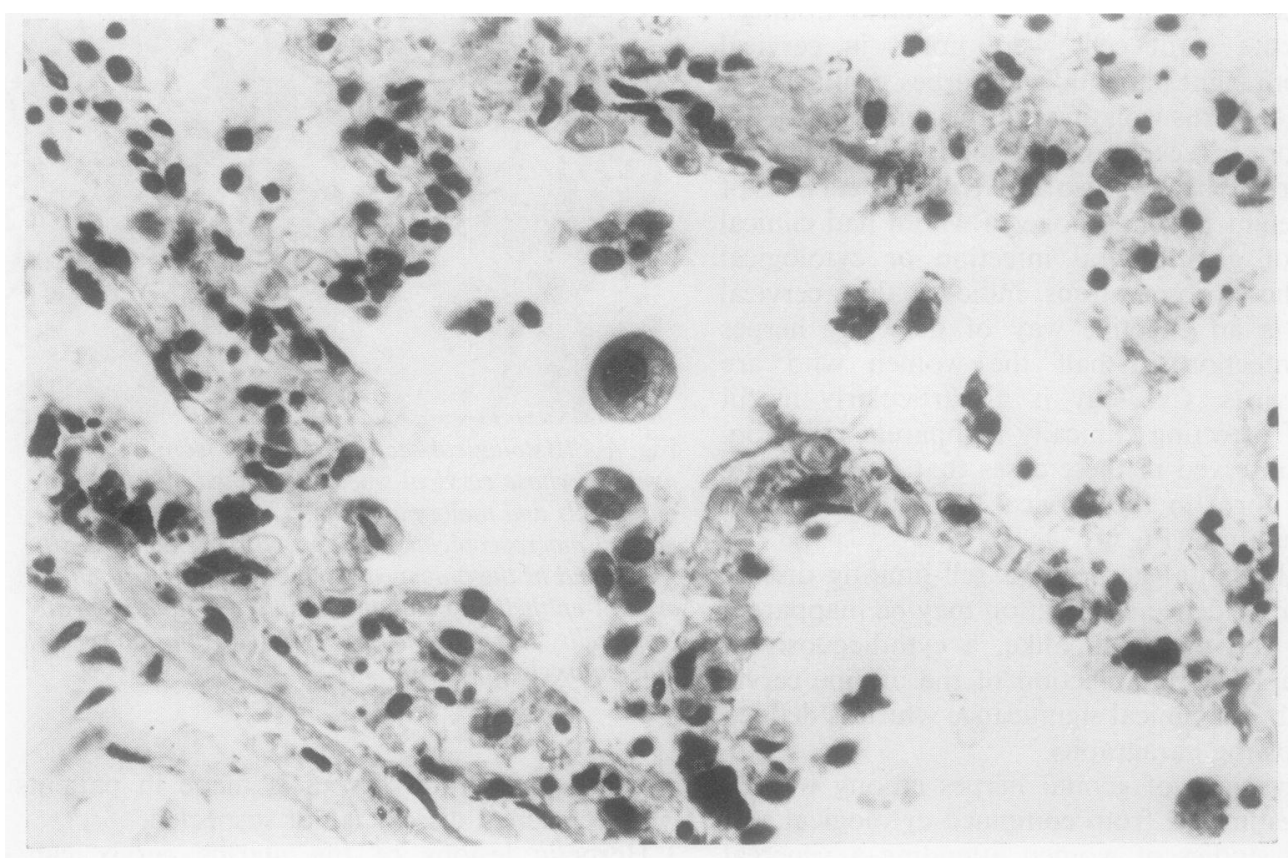

(a)

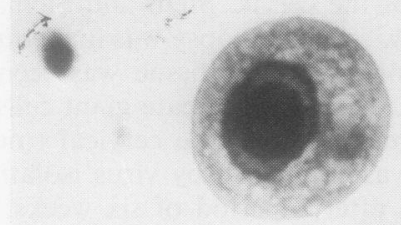

Fig. 5(a) Histological section of lung from renal allograft recipient showing a large inclusion-bearing cell in alveolar lumen. The diagnosis of cytomegalovirus infection was confirmed by virus isolation studies and electron microscopy of the virus-infected cell. $H$ and $E \times 400$

(b) Inclusion-bearing cell in Fig. 5a at higher magnification. $\times 1000$ 


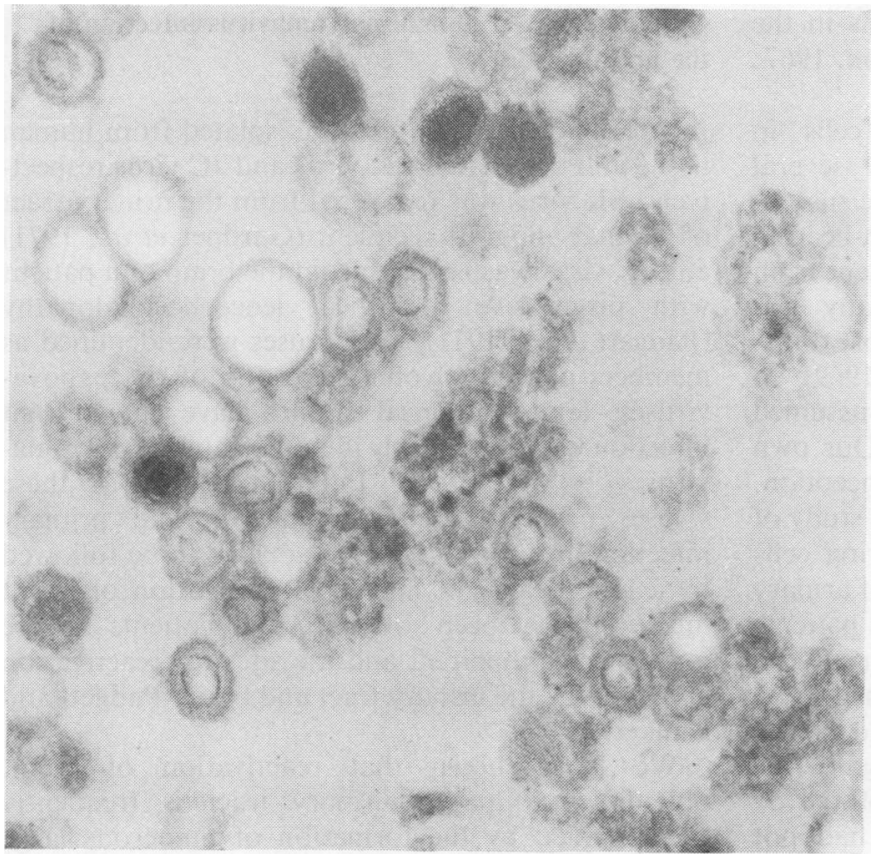

Fig. 6 Herpes virus particles identified in the inclusion-bearing cell shown in Fig. 5(b) after reprocessing for electron microscopy. Uranyl acetate $\times 50000$ antigens, the interpretation of the amount of neutralising antibody in any particular serum may be misleading when applied to any individual patient, as was done in many of the studies. It is significant, however, that a study by Skinner and his colleagues (1971), which has taken into account this problem of antigenic overlap, confirmed the results of earlier investigations.

Further studies are needed to determine the relationship between herpes simplex virus type 2 and squamous carcinoma of the cervix. With this in mind, we have embarked on a prospective study of $\mathbf{1 6 0}$ women with cervical dysplasia, which involves regular cytological, colposcopic, and virological investigation of the patients at three-monthly intervals over a period of three years in order to determine whether recurrent infection with herpes simplex or other viruses affects the rate of progression of the dysplasia to carcinoma in situ. It is anticipated that information from this study will help to clarify the role of genital herpes in cervical neoplasia.

\section{Cytodiagnosis of cytomegalic inclusion disease}

The large, basophilic, intranuclear, 'birds eye' inclusions (Figs 5(a), 5(b), and 6), which are a feature of cytomegalic inclusion disease, were first noted in histological sections of the liver, lung, and kidneys of a stillborn infant by Jesionek and Kiolemenoglou in 1904.
Fetterman (1952) was the first to demonstrate that inclusions can be detected in the urine of neonates with clinical evidence of the disease. The inclusionbearing cells are readily recognised in Papanicolaoustained smears of the urine sediment, and the important diagnostic feature is the presence of a large, basophilic, intranuclear inclusion body separated by a clearly defined halo from the thickened nuclear membrane. The cells are large (25-35 $\mu$ in diameter) and can be readily detected at low magnification. However, they may be few in number, and careful screening of several urine samples may be necessary for diagnosis. Medearis (1964) showed that cytology was a less sensitive method of detecting cytomegalic inclusion disease than virus isolation for he was able to demonstrate inclusion-bearing cells in the urine of only four out of seven infants who were excreting cytomegalovirus. Nevertheless, it should be borne in mind that isolation of cytomegalovirus in monolayer culture is a protracted procedure taking several weeks to accomplish as the virus grows slowly. Cytological examination of the urine sediment can play a useful role in the preliminary investigation of the infant and in establishing a differential diagnosis between neonatal cytomegalic disease and other congenital diseases that closely resemble it such as rubella and toxoplasmosis. It is our experience, and that of other cytopathologists, that the result of cytological investigation can be improved if a membrane 
filtration technique is used to trap the cells in the urine (Naib, 1963; Cederqvist and Johansson, 1967; Johnston et al., 1969).

The description of inclusion-bearing cells in infants with cytomegaloviruria prompted several cytological studies of adult patients who are susceptible to cytomegalovirus infection. Inclusion-bearing cells were reported in smears of urine sediment from patients receiving cytotoxic drug therapy for malignant disease or for the purposes of transplantation (Chang, 1970; Johnston et al., 1969). In these studies, the presence of inclusions was assumed to reflect infection with cytomegalovirus. Our own observations have shown this to be a misconception.

In a combined cytological and virological study of 82 renal allograft recipients, inclusion-bearing cells were noted in Papanicolaou-stained smears of urinary sediment in 31 patients $(38 \%)$. Ten of the 31 patients were found to be excreting cytomegalovirus, and human polyomavirus infection was confirmed in 11 others. A further 10 patients were found to be excreting both viruses in the urine. Cytomegalovirus was also isolated from the urine of 16 of the 51 patients in whom inclusion-bearing cells had not been detected. Our studies indicate that the inclusionbearing cells in the urine of immunosuppressed patients can be regarded as markers of virus infection of the urinary tract, but in the majority of cases the cytopathology is due to polyomavirus (Coleman, unpublished data).
Cytodiagnosis of human polyomavirus infection of the urinary tract

In 1971, two new viruses were isolated from human tissue and designated $\mathrm{BK}$ virus and $\mathrm{JC}$ virus respectively. BK virus was recovered from the urinary tract of a renal allograft recipient (Gardner et al., 1971) and $\mathrm{JC}$ virus was isolated from the brain of a patient with progressive multifocal leucoencephalopathy (Padgett et al., 1971). The viruses were identified as members of the polyoma subgroup of the papovaviruses, and serological studies have shown that infection with these newly identified human polyomaviruses is widespread. Initial exposure to these viruses occurs early in childhood, and primary infection in most individuals appears to be followed by a long period of latency. Reactivation of latent infection has been observed in patients whose immunity is impaired, and the sites for reactivation appear to be the urinary tract and brain (Padgett and Walker, 1976).

We have shown that reactivation of latent polyomavirus in the urinary tract is frequently accompanied by the formation of numerous large inclusion-bearing cells in the surface layers of the urothelium of the ureter and renal pelvis (Fig. 7) (Coleman et al., 1973; Coleman, 1975). These cells, which contain cyanophilic intranuclear inclusions, are readily exfoliated and may be found in large numbers in smears of the urine sediment of patients

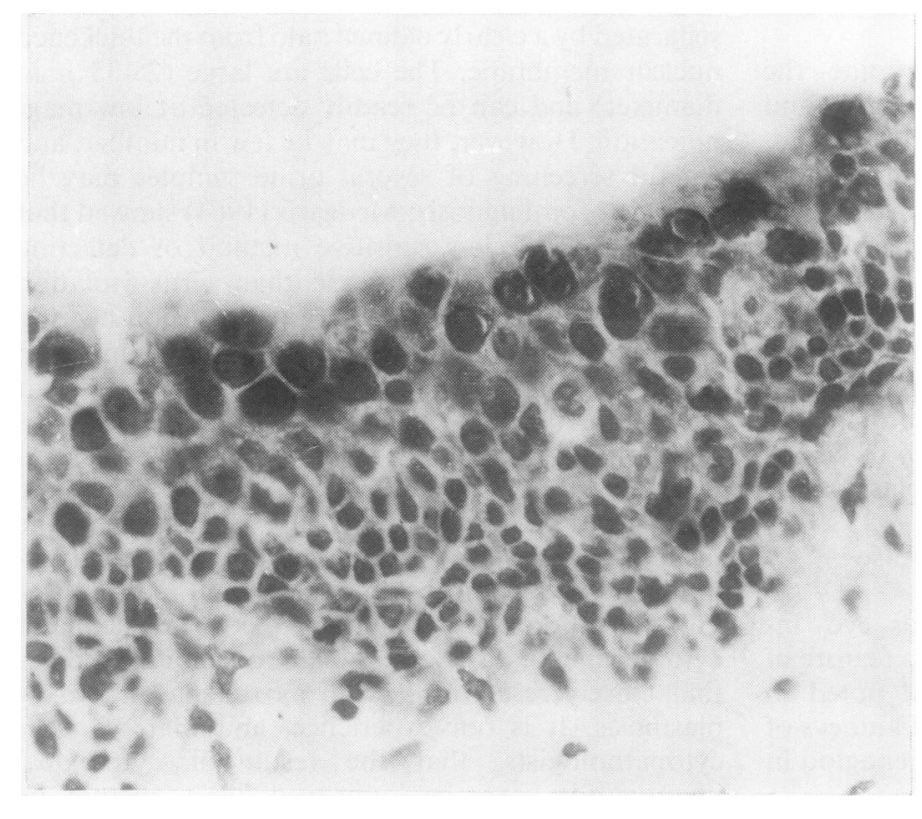

Fig. 7 Histological section of ureter from renal allograft recipient showing large inclusions in the nuclei of the surface cells of the urothelium. Numerous inclusion-bearing cells were noted in smears of urine sediment, and $B K$ virus was isolated from the urine. $H$ and $E \times 100$ 


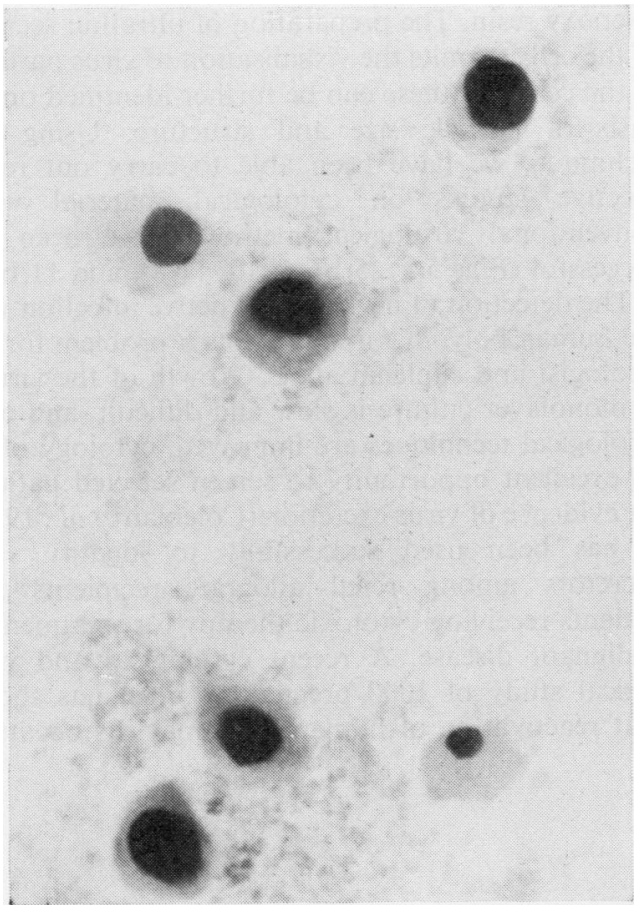

Fig. 8 Smear of urinary sediment from a woman aged 23 under treatment for Hodgkin's disease. Numerous urothelial cells with large basophilic nuclei were noted, and polyomavirus particles were found in negatively stained preparations of urine. Papanicolaou $\times 340$

who are actively excreting the virus (Figs 8 and 9). The nuclear structure of the polyomavirus-infected cells in the urine sediment presents a variable appearance, but two consistent morphological patterns can be recognised. The cell may present a classical 'birds eye' appearance and the nucleus contain a single cyanophilic inclusion separated from the thickened nuclear membrane by a clear halo (Fig. 9). Alternatively, the nucleus appears enlarged and densely cyanophilic but structureless and is surrounded by the thick nuclear membrane (Fig. 8).

As might be expected, these appearances present problems of diagnosis. The virus-infected cells may be confused with abnormal cells shed from a transitional-cell carcinoma. These tumour cells often have large hyperchromatic cyanophilic nuclei and prominent nuclear membranes. The difficulty is compounded by the fact that both types of cell may be present in the same specimen. However, careful scrutiny of the nuclear structure at high magnification will permit discrimination between virus-infected cells and cancer cells. The nuclei of the virus- infected cells appear amorphous and of uniform shape and size, whereas the nuclei of the cancer cells present a coarsely granular appearance due to the presence of chromatin clumps of varying size and shape unevenly distributed in the nucleus.

The inclusion-bearing cells, which result from infection with the polyomaviruses, closely resemble those seen in cytomegalic inclusion disease. It has been suggested that the two types of cell can be distinguished in the light microscope by observing whether inclusion bodies are present in the cytoplasm as well as in the nucleus. Clusters of small cyanophilic inclusions may be found in the cytoplasm of cytomegalovirus-infected cells. These are not present in polyomavirus-infected cells. It should be remembered, however, that viruses are not the only cause for cytoplasmic inclusions. Lipid degeneration in the cytoplasm or phagocytosis of polymorphs may prove a source of diagnostic error (Melamed and Wolinska, 1961).

In order to resolve the problems associated with the confirmation of virus infections suspected on cytological grounds, we have developed a technique that involves the reprocessing of inclusion-bearing cells in the Papanicolaou smear for examination in the electron microscope (Coleman et al., 1977). Single cells are picked off the smear and embedded

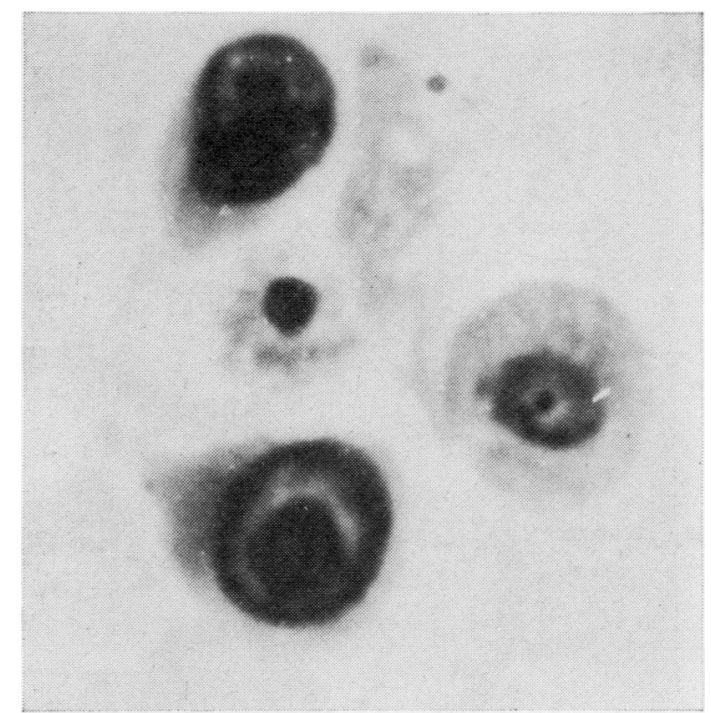

Fig. 9 One field of cells from smear of urine of renal allograft recipient showing two large virus-infected urothelial cells: one shows an obvious bird's eye inclusion, the other a basophilic, structureless nucleus with a thickened nuclear membrane. BK virus was isolated from the urine. Papanicolaou $\times 1000$ 


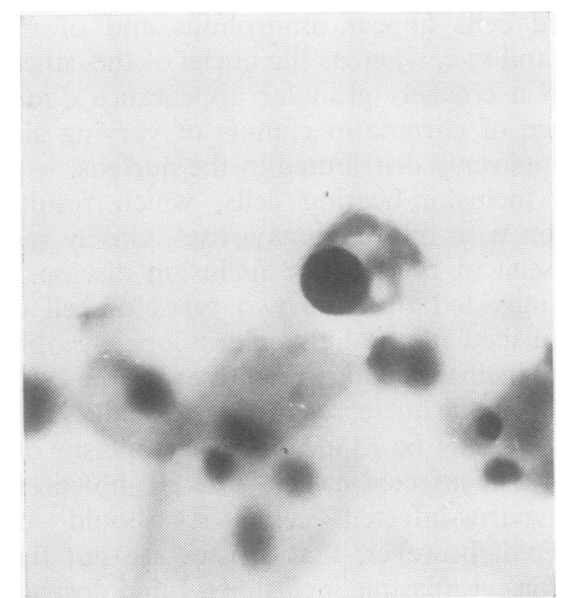

Fig. 10 A single virus-infected urothelial cell with large basophilic nucleus from the urine of a pregnant woman. Only a very few such cells were noted in the smear. Papanicolaou $\times 400$ in epoxy resin. The preparation of ultrathin sections of the cells permits the visualisation of virus particles in the cell, and these can be further identified on the basis of particle size and structure. Using this technique, we have been able to carry out retrospective studies on cytological material when conventional virological methods have been unsuccessful (Figs 5(a), 5(b), 6, 10, 11(a), and 11(b)).

The detection of new cases of active infection with the human polyomavirus presents a problem for the virologist and clinician alike. Growth of the viruses in monolayer culture is slow and difficult, and until virological techniques are improved, cytology offers an excellent opportunity to screen selected patients for evidence of virus excretion (Coleman et al., 1973). It has been used successfully to identify virus excretors among renal allograft recipients and patients receiving cytotoxic therapy for treatment of malignant disease. A recent cytological and virological study of 1000 pregnant women has shown that reactivation of human polyomavirus occurs in

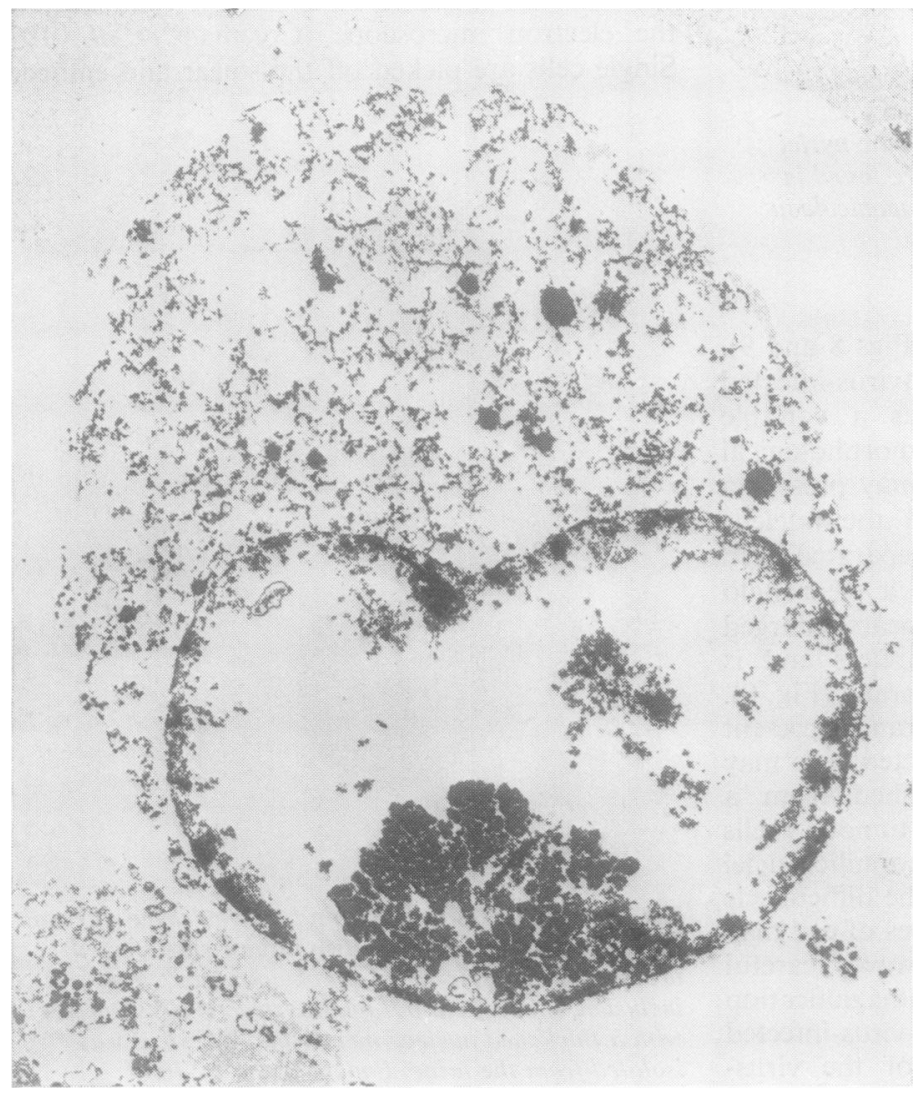

Fig. 11(a) Electron micrograph of urothelial cell shown in Fig. 10 showing crystalline masses in nucleus and prominent nuclear membrane. Uranyl acetate $\times 3565$ 
approximately $3 \%$. Studies are in progress to correlate maternal infection with fetal development and neonatal damage. Observations made by Koss on routine cytological material led to the detection of polyomavirus infection in 12 of 3648 specimens of urine received for malignant cell cytology from patients with a wide variety of primary disorders, which included hypertension, rheumatic heart disease, benign prostatic disease, and tuberculosis (unpublished data). The immunological competence of these 12 patients has not been investigated but the cytological diagnosis has been confirmed using the electron microscope technique described above.

There are many aspects of infection with the human polyomavirus that have yet to be explored. Primary infection has not been identified although it is known to occur in early childhood. JC virus has been identified in the oligodendroglial cells in the brain of patients with progressive multifocal leucoencephalopathy but infection with this virus does not appear to be confined to the brain as it has also been isolated from the urine of pregnant women. Active infection with BK virus has been reported in association with ureteric stenosis in renal allograft recipients but the role of urinary stasis and urothelial damage in virus reactivation has yet to be ascertained. These observations indicate that the potential for research into infection with these new viruses is wide. By using cytological markers as evidence of active virus infection, the physiological changes that predispose to polyomavirus infection can be further evaluated and the clinical significance of these new viruses may be ascertained.

\section{Cytological diagnosis of genital warts}

The papilloma viruses, which are associated with infectious warts of man, frequently form crystalline masses within the nuclei of the epithelial cells of these benign tumours. In histological section and cytological smears, cells from warty lesions appear to contain dense basophilic irregular nuclei and an

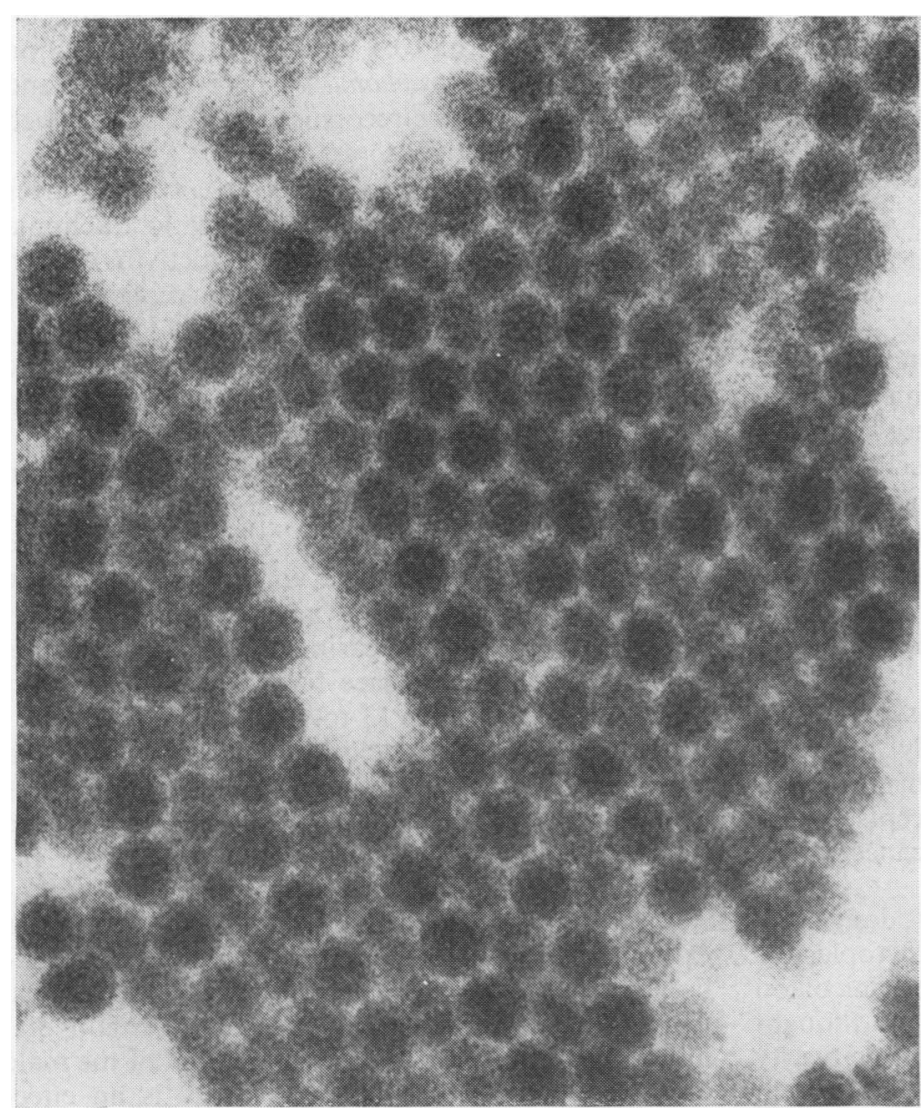

Fig. 11 (b) Figure 11(a) at higher magnification to show virus particles with icosahedral symmetry and diameter averaging $35 \mathrm{~nm}$. Morphology is consistent with polyomavirus. Uranyl acetate $\times 168820$ 


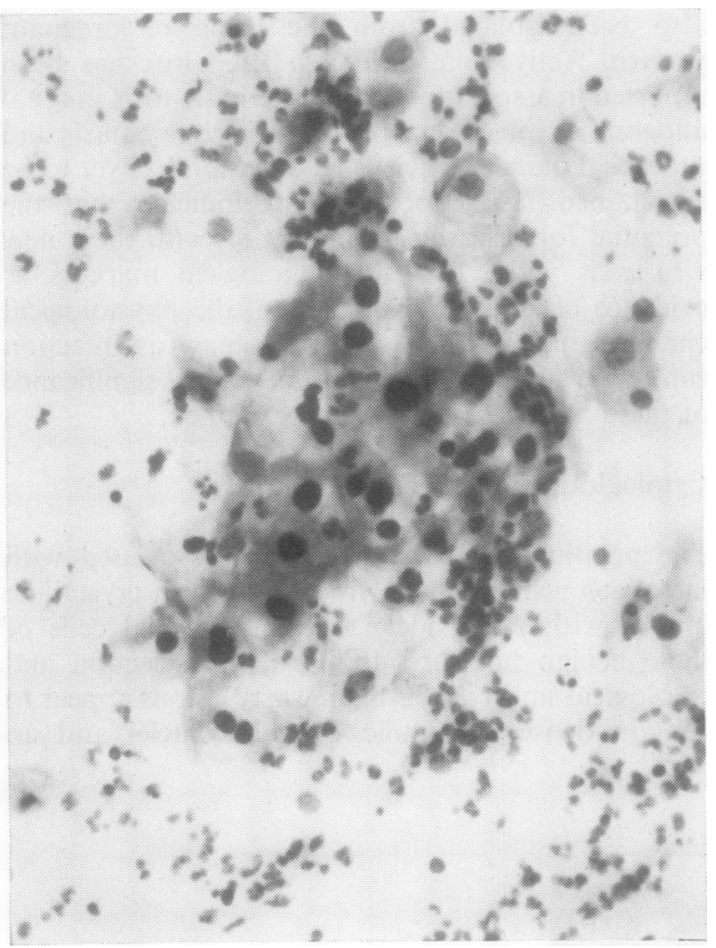

Fig. 12 Cervical smear containing cell derived from cervical warts showing nuclear hyperchromasia. There is also some variation in nuclear size and shape. Papanicolaou $\times 400$

intensely eosinophilic cytoplasm. The abnormal cells may be encountered in Papanicolaou-stained cervical smears taken from patients with condylomatous lesions of the cervix or vagina. As the cells derived from the warts are not readily distinguished from the dyskaryotic cells shed from premalignant lesions of the cervix, that is, dysplasia and carcinoma in situ, problems of differential diagnosis may arise (Naib and Masukawa, 1961; Purola and Savia, 1977) (Fig. 12).

It is possible that a number of lesions previously classified as cervical dysplasia actually represent condylomatous lesions of the cervix. If this proves to be the case, it will affect current concepts of the evolution of intraepithelial and invasive cancer of the cervix.

Very recently, abnormal epithelial cells, designated 'balloon cells' as they exhibit marked cytoplasmic vacuolation, have been described in Papanicolaou smears from the uterine cervix. They are thought to be derived from areas of koilocytosis or 'warty atypia' of the cervical epithelium. It has been suggested by Meisels and Fortin (1976) that koilocytosis represents an early stage of infection with wart virus before the formation of clinically detectable papillomatous lesions. Papillomavirus particles have been observed in ultrathin sections of cervical epithelium which in the light microscope showed the changes characteristic of koilocytosis (Laverty et al., 1978). These observations have yet to be confirmed.

\section{Diagnosis of oculoviral infection}

Acute conjunctivitis may be physical, chemical, allergic, or infectious in origin, and the clinical symptoms and signs of these different forms of conjunctivitis frequently overlap. In clinical practice, a differential diagnosis may be made on the clinical evidence and treatment started without waiting for the results of pathological tests as a week or more may elapse before these are available. The consequences of misdiagnosis can be serious, especially if the use of steroids is contemplated as a therapeutic measure.

In cases where a viral conjunctivitis is suspected, cytological investigation can provide a rapid method of confirming the clinical diagnosis before treatment. The cytological changes associated with infection due to Chlamydia trachomatis, herpes zoster, and herpes simplex can be recognised in Giemsa-stained smears of conjunctival scrapings.

Human ocular infection with $C$. trachomatis gives rise to the clinical diseases, panendemic trachoma and para trachoma (inclusion conjunctivitis). Both forms of infection are characterised by replication of the chlamydial agent in the cells of the tarsal conjunctiva with the formation of characteristic intracytoplasmic inclusions. In the early stages of infection, the inclusions are made up of clusters of microorganisms, $1 \mu$ in diameter, enveloped in a polysaccharide matrix which stains deeply with a haematoxylin or Giemsa stain. At a later stage the discrete microorganisms lie in a vacuole in the cytoplasm of the cell. The vacuole enlarges until it ruptures or 'bursts', releasing the microorganisms into the intercellular space from which they infect the adjacent cells (Figs 13 to 15 ).

Paratrachoma (or inclusion conjunctivitis) is a sexually transmitted disease, and the primary sites for multiplication of the chlamydial agent in this type of infection are the urethra and uterine cervix. Inclusion bodies have been described in Papanicolaoustained cervical smears, but their recognition is extremely difficult in view of the frequent contamination of smears with bacteria and cell debris. Cytology is of limited value in detecting chlamydial infection of the female genital tract and of the male urethra. On the other hand, cytology is an effec- 


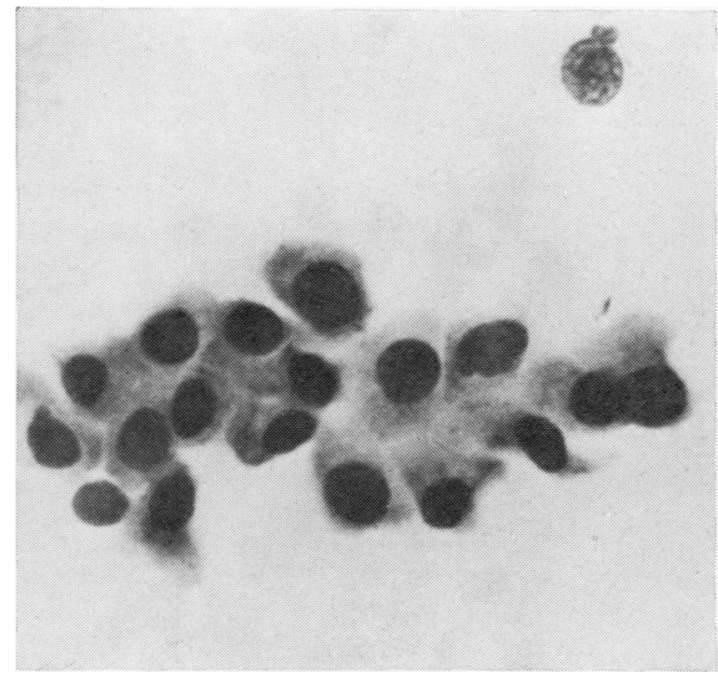

Fig. 13 Conjunctival scrape showing normal conjunctival cells. Giemsa $\times 400$

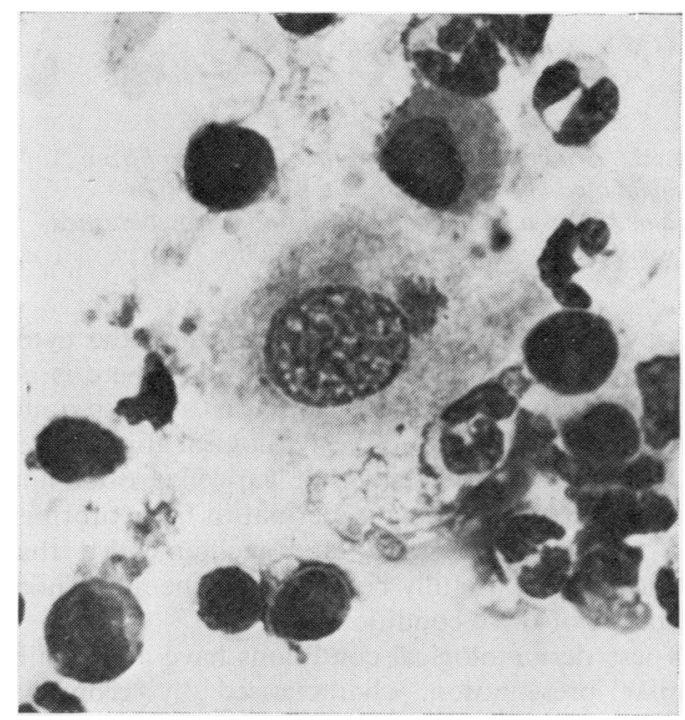

Fig. 14 Conjunctival scrape from patient with inclusion conjunctivitis showing small inclusion body composed of discrete particles. The inclusion is in the cytoplasm but is usually closely applied to the nucleus. Note inflammatory cells which are also present in the smear. Giemsa $\times 1000$

tive tool in the rapid diagnosis of inclusion conjunctivitis in the newborn who are infected intrapartum. Cytological confirmation of conjunctival infection with $C$. trachomatis can be obtained in $75 \%$ of patients when smears are taken in the acute

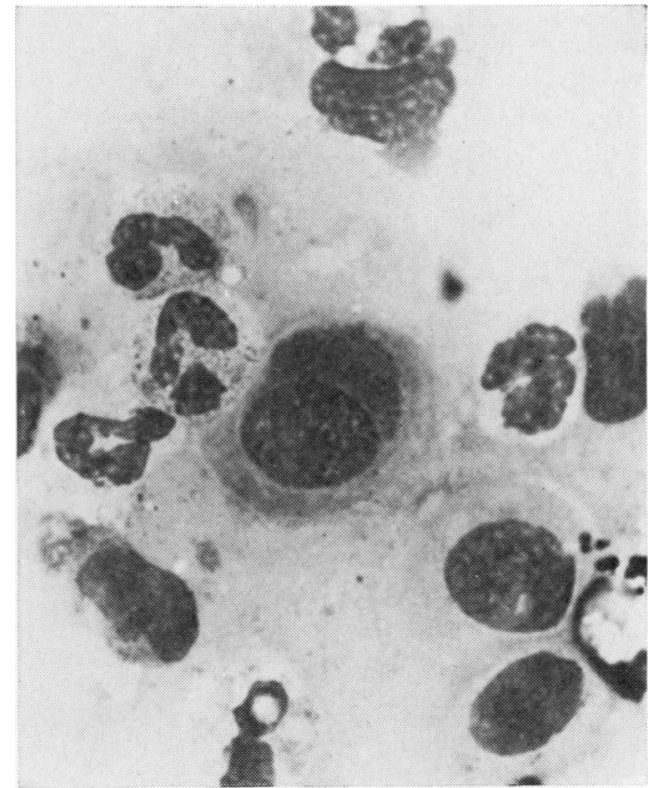

Fig. 15 Conjunctival cells from neonate with acute conjunctivitis. Note large crescentic intracytoplasmic inclusion closely applied to the nucleus.

stages of the disease (Dawson and Schachter, 1967; Darougar et al., 1971).

Alternative methods of diagnosing chlamydial infection include immunofluorescence and immunoperoxidase staining of conjunctival smears. Giemsa staining has been found to be slightly less sensitive than the immunocytochemical methods but is more convenient for clinic use. Moreover, problems of artifact are minimal with the Giemsa method (Woodland et al., 1978). Inoculation of monolayer cultures of irradiated McCoy cells with conjunctival swabbings provides another method of detecting C. trachomatis, but facilities for this investigation are available in only a few specialist laboratories, thereby emphasing the value of cytology in routine clinical practice.

The cytological change associated with conjunctival infection with herpes simplex virus and herpes zoster is the formation of syncytia of conjunctival cells. These appear to be larger and more numerous in varicella/zoster virus infection than in herpes simplex infection (Fig. 16).

\section{Diagnosis of dermatological diseases}

The diagnosis of viral infection of the skin by cytological methods was first described by Tyzzer (1905), who perfected the technique by experimenting on convicts during an epidemic of varicella in a penal 


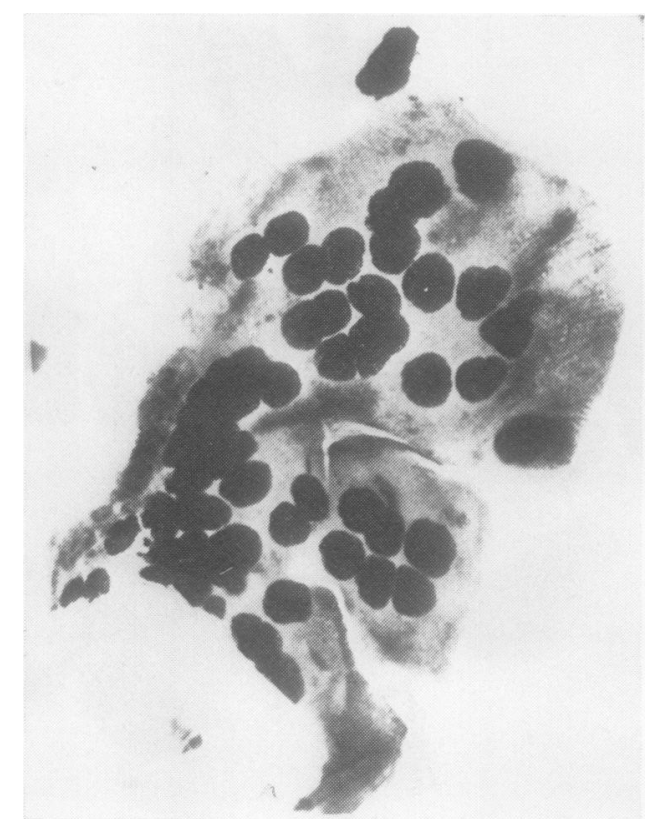

Fig. 16 Syncytium of cells in corneal scrape from a case of herpes zoster infection of the cornea. Giemsa $\times 1000$

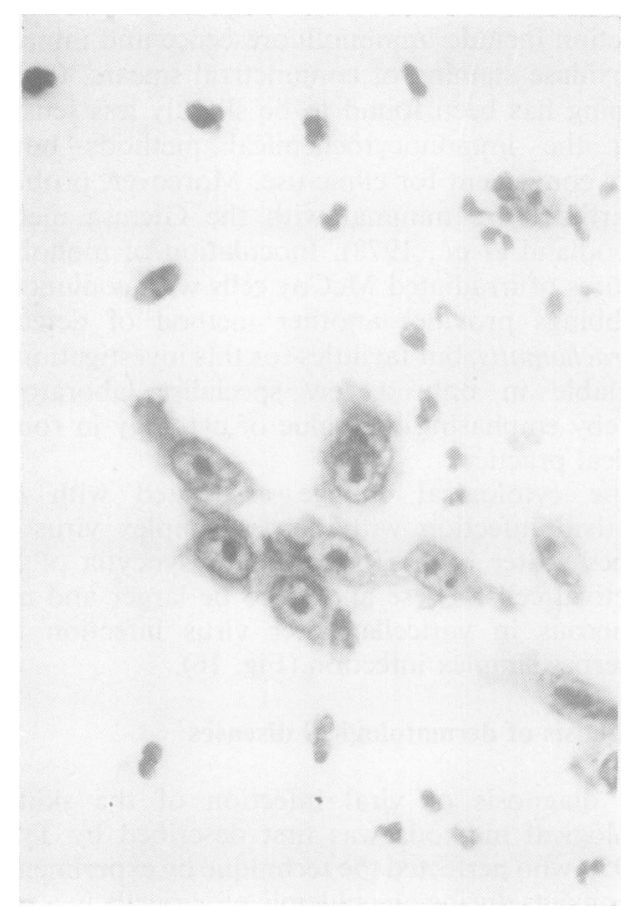

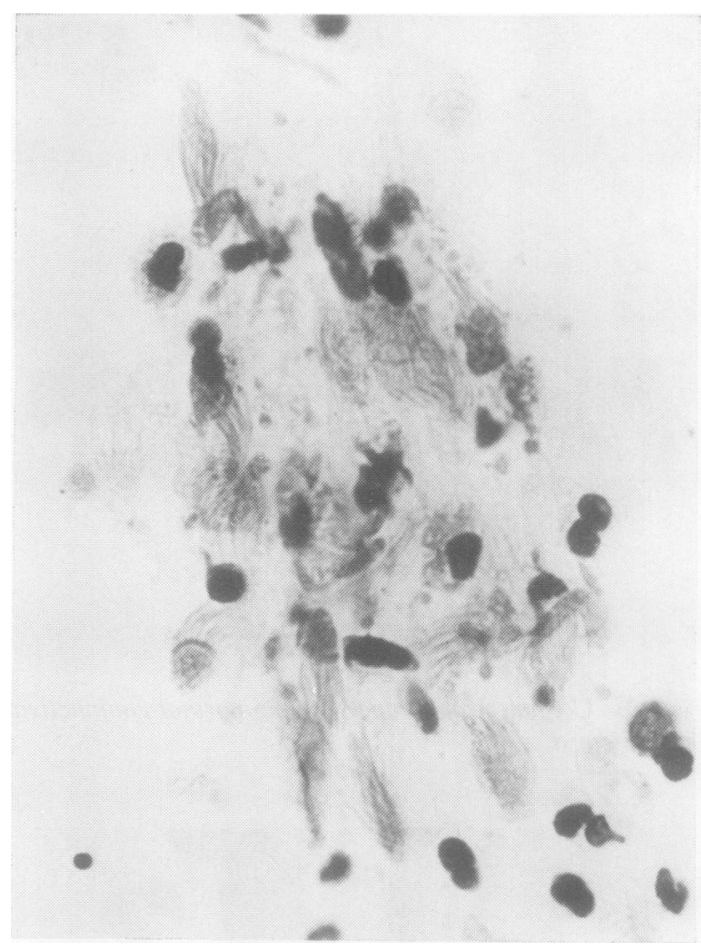

Fig. 18 Numerous ciliated tufts of cytoplasm from desquamated bronchial epithelial cells in sputum obtained from a man aged 33 with influenza confirmed by virus isolation. Papanicolaou $\times 1000$

colony in 1906. Although he advocated the cytological method for 'use at the bedside', there is no indication that this suggestion was adopted until Tzanck (1948) compared the cytological appearances of smears from the lesions of varicella zoster and herpes simplex, pemphigus, dermatitis herpetiformis, and bullous pemphigoid, and recommended that cytology could usefully be applied to the differential diagnosis of these conditions.

These dermatological conditions have a clinically similar presentation, characterised by crops of vesicles. Their aetiologies, however, are quite distinct, only herpes simplex and varicella zoster being due to viruses. In the herpes infections and in pemphigus, the vesicles form in the epidermal layer of the skin and hence contain numerous exfoliated epithelial cells. In dermatitis herpetiformis and bullous pemphigoid, the blisters are subepidermal, and the blister cavity contains an inflammatory exudate in which eosinophils predominate. Smears

Fig. 17 Acantholytic cells in smear of vesicle fluid from a case of pemphigus. Note the prominent nucleoli. Papanicolaou $\times 400$ 
prepared from vesicle fluid or from scrapings taken from the base of the vesicles present characteristic cytological patterns.

The diagnostic cell in vesicles due to herpes simplex and varicella-zoster infection is the multinucleate giant cell, which in no way differs from that found in cervical smears (Figs 1 and 2). The characteristic cells found in the bullae of pemphigus vulgaris and pemphigus foliaceus are the acantholytic cells (Fig. 17), which appear in smears as discrete, rounded cells with large nuclei occupying two-thirds of the cell. Multiple large nucleoli or mitotic figures are often seen and are an indication of cell division occurring in the prickle cell layer.

While virus isolation, direct electron microscopy, and biopsy are alternative methods for the diagnosis of these vesicular lesions, cytology offers a quick and simple method of distinguishing them, especially if the lesion affects the mucous membrane of the mouth or vagina. Scrapings obtained from the base of the vesicles with a scalpel or fine metal dental spatula often provide a more cellular smear.

\section{Cytological diagnosis of respiratory viral infection}

The ciliated tufts of cytoplasm that can occasionally be seen in abundance in smears of sputum were first described by Papanicolaou in 1956, who gave this cytological pattern the name ciliocytophthoria (CCP) (Fig. 18). He thought that these ciliated fragments of bronchial epithelium were a precursor of malignant disease of the bronchus, and it was only later that their association with acute viral infection of the upper respiratory tract was noted (Pierce and Hirsch, 1958). It has been found that CCP can be detected in the sputum of about half the
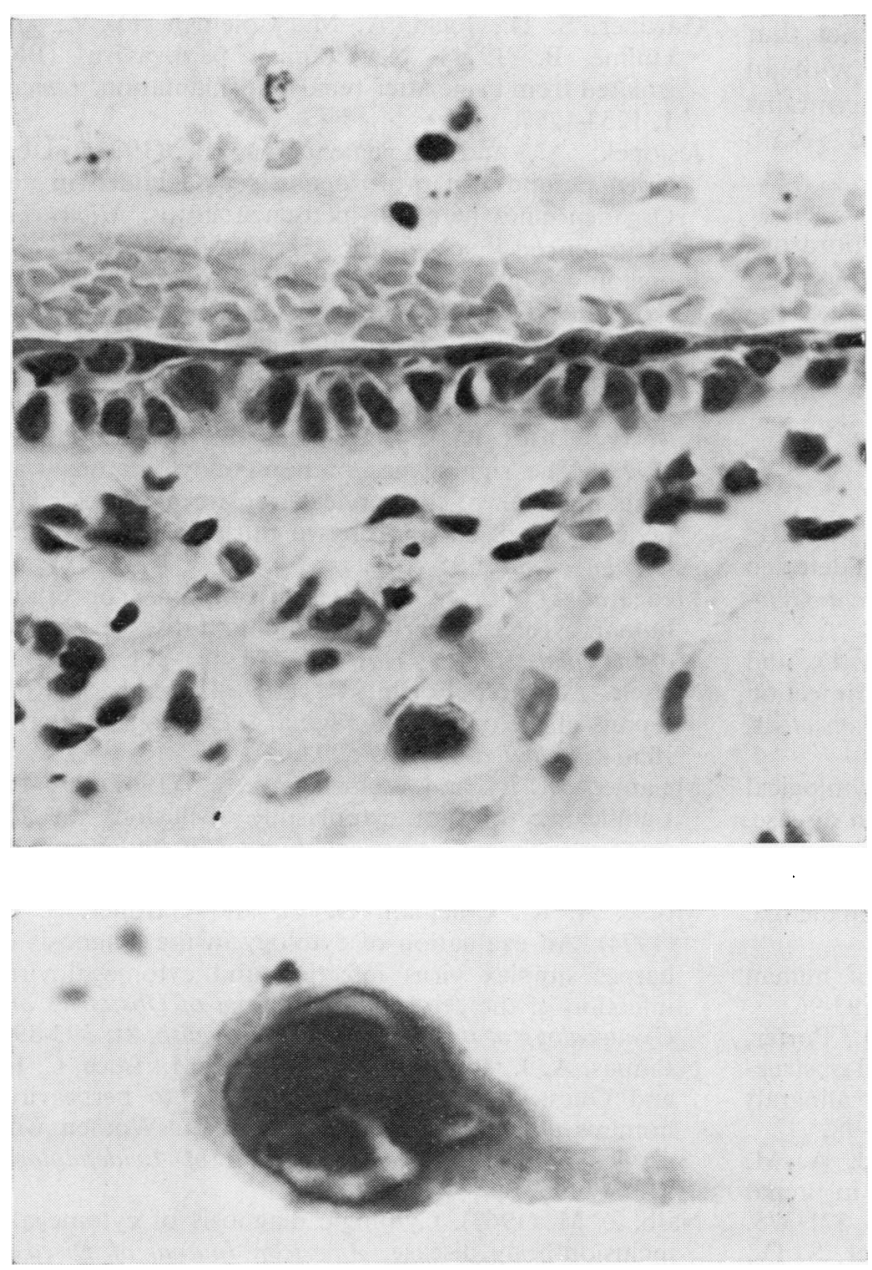

Fig. 19 Histological section of trachea from a man aged 54 with aortic stenosis who died four days after the onset of influenza, showing destruction of the tracheal epithelium down to the basal layers. There is a slight infiltration of mononuclear cells and capillary congestion. Infection confirmed by virus isolation. $H$ and $E \times 400$

Fig. 20 Herpes simplex infected cell in sputum showing morphological changes in nucleus and cytoplasm similar to those seen in squamous carcinoma of bronchus. Papanicolaou $\times 1000$ 
patients with acute respiratory virus infection in the absence of secondary bacterial infection. CCP is a reflection of the destructive effect of the respiratory viruses on the bronchial epithelium (Fig. 19). Occasionally, it occurs after bronchoscopy or radiotherapy, which can cause rapid destruction of the bronchial epithelium.

The multinucleate giant cell of herpes simplex may be seen in sputum samples obtained from patients with herpetic lesions of the mouth, pharynx, or tracheal mucosa. Respiratory herpes is particularly frequent in patients receiving cytoxic drug therapy, and we have observed that the distinction between herpes-infected cells and malignant cells in these patients is not always straightforward. The giant cells in sputum often have intensely eosinophilic cytoplasm, which may be drawn out into long processes, and the distinction between them and 'tadpole' cells from a squamous carcinoma of bronchus needs to be made with care (Fig. 20). The diagnostic problem is complicated by the fact that herpetic lung infection is often associated with an intense local necrosis, and the sputum contains abundant necrotic cell debris and blood (Naib et al., 1968).

Mr Niall MacHugh, senior medical laboratory scientific officer, Department of Pathology, St Mary's Hospital Medical School, processed the cells shown in Figs 5, 6, 10, and 11 for electron microscopy.

\section{References}

An, S. H. (1969). Herpes simplex virus infection detected on routine gynecological cell specimens. Acta Cytologica, 13, 354-358.

Beilby, J. O. W., Cameron, C. H., Catterall, R. D., and Davidson, D. (1968). Herpes virus hominis infection of the cervix associated with gonorrhoea. Lancet, 1, 1065-1066.

Cederqvist, L., and Johansson, O. (1967). Cytological diagnosis of generalised cytomegalic inclusion disease. Acta Pediatrica Scandinavica, 56, 127-131.

Chang, S. C. (1970). Urinary cytologic diagnosis of cytomegalic inclusion disease in childhood leukaemia. Acta Cytologica, 14, 338-343.

Coleman, D. V. (1975). The cytodiagnosis of human polyomavirus infection. Acta Cytologica, 19, 93-96.

Coleman, D. V., Field, A. M., Gardner, S. D., Porter, K. A., and Starzl, T. E. (1973). Virus-induced obstruction of the ureteric and cystic duct in allograft recipients. Transplantation Proceedings, 5, 95-98.

Coleman, D. V., Gardner, S. D., and Field, A. M. (1973). Human polyomavirus infection in renal allograft recipients. British Medical Journal, 3, 371-375.

Coleman, D. V., Mackenzie, E. F. D., Gardner, S. D.,
Poulding, J. M., Amer, B., and Russell, W. J. I (1978). Human polyomavirus (BK) infection and ureteric stenosis in renal allograft recipients. Journal of Clinical Pathology, 31, 338-347.

Coleman, D. V., Russell, W. J. I., Hodgson, J., Tun Pe, and Mowbray, J. F. (1977). Human papovavirus in Papanicolaou smears of urinary sediment detected by transmission electron microscopy. Journal of Clinical Pathology, 30, 1015-1020.

Darougar, S., Dwyer, R. St. C., Treharne, J. D., Harper, I. A., Garland, J. A., and Jones, B. R. (1971). A comparison of laboratory methods of diagnosis of chlamidial infection. In Trachoma and Related Disorders Caused by Chlamydial Agents (Excerpta Medica International Congress Series, 223), edited by $\mathbf{R}$. L. Nichols, Excerpta Medica, Amsterdam. pp. 445-460.

Dawson, C. R., and Schachter, J. (1967). TRIC agent infections of the eye and genital tract. American Journal of Ophthalmology, 63, 1288-1298.

Fetterman, G. H. (1952). A new laboratory aid in the clinical diagnosis of inclusion disease of infancy. American Journal of Clinical Pathology, 22, 424-425.

Gardner, S. D., Field, A. M., Coleman, D. V., and Hulme, B. (1971). New human papovavirus (BK) isolated from urine after renal transplantation. Lancet, 1, 1253-1257.

Jesionek, A., and Kiolemenoglou, B. (1904). Über einen Befund von protozoënartigen Gebilden in den Organen eines hereditär-luetischen Fötus. Münchener Medizinische Wochenschrift, 51, 1905-1907.

Johnston, W. W., Bossen, E. H., Amatulli, J., and Rowlands, D. T., Jr. (1969). Exfoliative cytopathologic studies in organ transplantation. II. Factors in the diagnosis of cytomegalic inclusion disease in urine of renal allograft recipients. Acta Cytologica, 13, 605-610.

Laverty, C. R., Russell, P., Hills, E., and Booth, N. (1978). The significance of non-condylomatous wart virus infection of the cervical transformation zone. A review with discussion of two illustrative cases. Acta Cytologica, 22, 195-201.

Medearis, D. N., Jr. (1964). Observations concerning human cytomegalovirus infection and disease. Bulletin of the Johns Hopkins Hospital, 114, 181-211.

Meisels, A., and Fortin, R. (1976). Condylomatous lesions of the cervix and vagina. I. Cytologic patterns. Acta Cytologica, 20, 505-509.

Melamed, M. R., and Wolinska, W. H. (1961). On the significance of intracytoplasmic inclusions in the urinary sediment. American Journal of Pathology, 38, 711-719.

Morse, A. R., Coleman, D. V., and Gardner, S. D. (1974). An evaluation of cytology in the diagnosis of herpes simplex virus infection and cytomegalovirus infection of the cervix uteri. Journal of Obstetrics and Gynaecology of the British Commonwealth, 81, 393-398.

Nahmias, A. J., Josey, W. E., Naib, Z. M., Luce, C. F., and Guest, B. A. (1970). Antibodies to herpesvirus hominis types 1 and 2 in humans. II. Women with cervical cancer. American Journal of Epidemiology, 91, 547-552.

Naib, Z. M. (1963). Cytologic diagnosis of cytomegalic inclusion-body disease. American Journal of Diseases 
of Children, 105, 153-159.

Naib, Z. M., and Masukawa, N. (1961). Identification of condyloma acuminata cells in routine vaginal smears. Obstetrics and Gynaecology, 18, 735-738.

Naib, Z. M., Nahmias, A. J., and Josey, W. E. (1966). Cytology and histopathology of cervical herpes simplex infection. Cancer, 19, 1026-1031.

Naib, Z. M., Nahmias, A. J., Josey, W. E., and Kramer, J. H. (1969). Genital herpetic infection: association with cervical dysplasia and carcinoma. Cancer, 23, 940-945.

Naib, Z. M., Stewart, J. A., Dowdle, W. R., Casey, H. L., Marine, W. M., and Nahmias, A. J. (1968). Cytological features of viral respiratory tract infections. Acta Cytologica, 12, 162-171.

Padgett, B. L., and Walker, D. L. (1976). New human papovaviruses. Progress in Medical Virology, 22, 1-35.

Padgett, B. L., Walker, D. L., ZuRhein, G. M., and Eckroade, R. J. (1971). Cultivation of papova-like virus from human brain with progressive multifocal leucoencephalopathy. Lancet, 1, 1257-1260.

Papanicolaou, G. N. (1956). Degenerative changes in ciliated cells exfoliating from the bronchial epithelium as a cytologic criterion in the diagnosis of diseases of the lung. New York State Journal of Medicine, 56, 2647-2650.

Pierce, C. H., and Hirsch, J. G. (1958). Ciliocytophthoria: relationship to viral respiratory infections of humans. Proceedings of the Society for Experimental Biology and Medicine, 98, 489-492.

Purola, E., and Savia, E. (1977). Cytology of gynecologic condyloma acuminatum. Acta Cytologica, 21, 26-31.

Rawls, W. E., Tompkins, W. A. E., and Melnick, J. L. (1969). The association of herpes virus type 2 and carcinoma of the uterine cervix. American Journal of Epidemiology, 89, 547-554.

Royston, I., and Aurelian, L. (1970). The association of genital herpes virus with cervical atypia and carcinoma in situ. American Journal of Epidemiology, 91, 531-538.

Skinner, G. R. B., Thouless, M. E., and Jordan, J. A. (1971). Antibodies to type 1 and type 2 herpes virus in women with abnormal cervical cytology. Journal of Obstetrics and Gynaecology of the British Commonwealth, 78, 1031-1038.

Stein, P. J., and Siciliano, A. (1966). Necrotizing herpes simplex viral infection of the cervix during pregnancya mimic of squamous cell carcinoma. American Journal of Obstetrics and Gynaecology, 94, 249-252.

Stern, E., and Longo, L. D. (1963). Identification of herpes simplex virus in a case showing cytological features of viral vaginitis. Acta Cytologica, 7, 295-299.

Tyzzer, E. E. (1905). The histology of the skin lesions in varicella. Journal of Medical Research, 14, 361-392.

Tzanck, A. (1948). Le cytodiagnostic immédiat en dermatologie. Annales de Dermatologie et Syphiligraphie, 8, 205-218.

Willcox, R. R. (1968). Primary infection of herpes simplex causing necrotic cervicitis. British Journal of Clinical Practice, 22, 358-363.

Woodland, R. M., El-Sheikh, H., Darougar, S., and Squires, S. (1978). Sensitivity of immunoperoxidase and immunofluorescence staining for detecting chlamydia in conjunctival scrapings in cell culture. Journal of Clinical Pathology, 31, 1073-1077.

Requests for reprints to: Dr D. V. Coleman, Department of Clinical Cytology and Cytogenetics, St Mary's Hospital, Praed Street, London W2 1NY, UK. 